accident Á plusieurs victimes, il est souvent difficile de garder en tête Á la fois les victimes et les moyens dont vous disposez. Le tableau croisé est un formulaire qui permet de diriger et de documenter efficacement une intervention sur un accident Á plusieurs victimes. Le principe du tableau croisé est que vous allez regrouper les informations sur les victimes, comme leur numéro et leur catégorie de triage sur les lignes horizontales de votre tableau (l'axe des X). Les information sur les vecteurs (heure d'appel, heure d'arrivée) seront notées sur les colonnes ( l'axe des y). L'heure de prise en charge de chaque victime par une unité est notée Á l'intersection correspondante. L'heure d'Évacuation vers l'hôpital est notée au bout de chaque colonne et de chaque ligne. Ce formulaire permet de garder une vue d'ensemble des opérations de secours Á victime ainsi que de documenter l'action de chaque Équipe et le devenir de chaque patient. Il est utilisable dû l'arrivée de la première Équipe sur place, puisqu'il suffit d'un stylo et d'une feuille de papier pour le réaliser. Dans notre expérience, une feuille de format A4 européen permet de gérer une intervention pour une dizaine de victime, une feuille de format A5 jusqu'Á une trentaine.

Prehosp Disaster Med 2011;26(Suppl. 1):s85-s86

doi:10.1017/S1049023X11002895

(A306) Community Resilience and the Christchurch Earthquake: Best Laid Plans or Practise Made Perfect? A.R.G. Humphrey, J. Mitchell, S.K. Mcbride

Medical Officer of Health, Canterbury, New Zealand

On February 22, 2011 at 12:51 pm an earthquake measuring 6.3 on the Richter scale struck the city of Christchurch, population 376,700 in the South Island of New Zealand. This followed a 7.3 magnitude earthquake in September 2010, but the shallowness $(5 \mathrm{~km})$ and proximity of the February earthquake to the central city, resulted in far more devastation, with Modified Mercalli scores reaching ten in some areas and upward ground acceleration exceeding $2.4 \mathrm{G}$. The application of the Coordinated Incident Management System (CIMS) routinely used by New Zealand Civil Defence agencies was swift, innovative and efficient, facilitating rapid deployment of local and international emergency teams and response resources. The effectiveness of this response was partially attributed to lessons learnt from the September earthquake which, with hindsight, was a practise for the more serious February event. The community response was equally remarkable, with standard approaches to measuring preparedness and resilience suggesting that community resilience in Canterbury was high. A number of initiatives by the NewZealand Ministry of Civil Defence and Emergency Management may have fostered some of this resilience,particularly communitybased resilience-building projects initiated by the Regional Emergency Management Office on 2009 and 2010, supported by the Ministry of Civil Defence and Emergency Management. In addition, website education resources and media promotion ("Get Ready Get Thru") and a travelling exhibition called "The Pandemic Roadshow" had been particularly well received and remembered by Canterbury residents. However, two key events provided an impetus for the Canterbury community to burnish its resilience. First, the Swine flu (AH1N1) pandemic in 2009 resulted in a greater awareness of public health in emergencies along with a doubling of neighbourhood support groups.
Secondly, the September 2010 earthquake resulted in the establishment of the student army of volunteers and improvement of public information management. This presentation will describe the markers of community resilience following the Christchurch earthquake and discuss how such resilience can be fostered in communities where emergency preparedness is not recognised as a priority.

Prehosp Disaster Med 2011;26(Suppl. 1):s86

doi:10.1017/S1049023X11002901

(A307) Disaster Task Force's Management Support at Emergency Response Phase in the Merapi Eruption November 2010

\section{H. Wartatmo}

Centre of Health Service Management, Faculty of Medicine, Yogyakarta, Indonesia

Background: Merapi, the most active volcano in the world, erupted on the 26th October 2010 at 17.02, and followed by several eruptions. The biggest eruption was on the 5 th of November 2010. Damages were catastrophic: 386 people killed, and more than $\$ 400$ million lost. A wide area of fertile lands and settlements were destroyed which resulted in more than 200.000 refugees. This disaster had impact to 2 provinces and 6 districts. At the emergency phase, a special task force was established by central government of Indonesia. This paper aims to evaluate the task force and the role of its management support during the acute phase in the disaster.

Method: an input and process evaluation of task force work was implemented.

Results: The input evaluation shows that the task force members for emergency response came from central, provincial, district government employees, universities and non government organisation members. The financial sources are from public and private funding. The activities process of task force in forms of health response command system, temporary information system, communication and telecommunication system, supporting the volunteer groups, managing the refugees camps, implementing surveillance system, and backed up the local district health officers. There were problems of programs coordination and channelling the budget from national treasury due to the multiple eruptions. Most of these problems were solved by a management support team for the task force.

Conclusion: The multiple strikes of Merapi eruption needs better human resources management and financial support. During Merapi eruption, it is proved that a management support for emergency response task force is important. This management support allowed better control and coordination of available resources.

Prehosp Disaster Med 2011;26(Suppl. 1):s86

doi:10.1017/S1049023X11002913

\section{(A308) Come Hell and Cold, High Water...}

\section{A.J. Mclean}

Fargo, United States of America

It is extremely rare in disaster mental health annals to have consistent psychosocial interventions pre-disaster. For the third year in a row, the Red River Valley of the United States and Canada 